\title{
Antimicrobial effects of different extracts of medicinally used green leafy vegetables collected from local market of Dhaka, Bangladesh
}

\author{
${ }^{1,2}$ Hossaini, F., ${ }^{1, *}$ Munshi, S.K. and ${ }^{3}$ Chakraborty, M. \\ ${ }^{1}$ Department of Microbiology, Stamford University Bangladesh, 51. Siddeswari Road, Dhaka 1217, \\ Bangladesh \\ ${ }^{2}$ Nutrition and Clinical Services Division, Emerging infections and Parasitology Laboratory, International \\ Centre for Diarrheal Disease Research, Bangladesh (icddr,b), 68, Shaheed Tajuddin Ahmed Sarani, \\ Mohakhali, Dhaka 1212, Bangladesh \\ ${ }^{3}$ Institute of Biotechnology and Genetic Engineering, Bangabandhu Sheikh Mujibur Rahman Agricultural \\ University, Salna, Gazipur 1706, Bangladesh
}

\begin{abstract}
Article history:
Received: 5 January 2020

Received in revised form: 17 January 2020

Accepted: 3 February 2020

Available Online: 17

February 2020

Keywords:

Antimicrobial effect,

Green leafy vegetables,

Traditional medicine,

Solvent extracts
\end{abstract}

DOI:

https://doi.org/10.26656/fr.2017.4(3).017

\begin{abstract}
The present study was carried out to determine the antimicrobial efficacy of green leafy vegetable samples which are traditionally used as medicinal herbs. Therefore, three samples each of Neem (Azadirachta indica, leaves), Ivy Gourd (Coccinia grandis, leaves), Water Spinach (Ipomoea aquatica, leaves) and Skunkvine (Paederia foetida, leaves) were collected and subjected to microbiological analysis, and agar well diffusion and microdilution assays to check antimicrobial activity. The samples contained total viable bacteria and fungi up to $10^{7}$ and $10^{5} \mathrm{CFU} / \mathrm{g}$, respectively. Staphylococcus spp., Klebsiella spp. and Pseudomonas spp. were recovered in all the samples. All the samples showed potential antibacterial activity against most of the tested bacteria, especially their ethanolic and methanolic extracts. Although, crude and hot water extracts almost had no effect on the bacterial growth. The MIC value of the samples was found in a range of $3 \mathrm{mg} / \mathrm{mL}$ to $12 \mathrm{mg} / \mathrm{mL}$ and the average MIC value was recorded to be $6 \mathrm{mg} / \mathrm{mL}$. Overall, the findings of the present study justified the therapeutic potential of the tested green leafy vegetable samples.
\end{abstract}

\section{Introduction}

Since ancient times, green leafy vegetables have been used as medicine and have a great impact on our diet and nutrition. They are known to be the sources of carbohydrates, fats, important proteins, vitamins, minerals, essential amino acids, and fibers (Bhat and AlDaihan, 2014). Many widely consumed vegetables, apart from medicinal herbs, may comprise of essential phytochemicals with pharmacological properties (Amagase and Farnsworth, 2011). In addition, certain indigenous vegetables, especially dark colored leafy green vegetables have been reported to contain bioactive compounds such as alkaloids, tannins, flavonoids, and phenolic compounds with antioxidant and antimicrobial activities ( Bhojane et al., 2014). Vegetables merely have any adverse effects as medicinal plants (Matasyoh et al., 2009), and capable to synthesize a variety of secondary metabolites of relatively complex structures with antimicrobial effects (Dhiman et al., 2012). Green leafy vegetables also contain a large number of compounds those have anti-diabetic (Kesari et al., 2005), anti- histaminic (Yamamura et al., 1998), anti-carcinogenic (Rajeshkumar et al., 2002) and hypo-lipidemic (Khanna et al., 2002) properties.

Due to the increasing rate of antibiotic resistance, there is an urgent need of novel antimicrobial agents against emerging and re-emerging infectious diseases (Chakraborty et al., 2020). Therefore, researchers are focusing more on traditional or folk medicine in recent times (Sukanya et al., 2009). Plants produce a number of bioactive molecules, rendering them a rich source of various medicines. Several studies reported on the use of many plant-derived products with antimicrobial properties against different pathogenic bacteria and fungi (Sukanya et al., 2009; Ahmed et al., 2014; Jahan et al., 2018; Chakraborty et al., 2020). Green leafy vegetables have been a valuable source of natural products for maintaining human health as well as can possibly be applied for prevention and therapeutic purposes (Rattanasena, 2012). Many of them, though, remain unexplored. 
The present study was therefore designed to investigate the antibacterial properties of green leafy vegetables using their crude and solvent extracts against some bacterial strains by agar well diffusion method as well as by MIC assay using microdilution technique. Microbiological quality of the vegetables was also checked.

\section{Materials and methods}

\subsection{Study area, sampling and sample processing}

The present study was carried out with three samples each of four types of green leafy vegetables including Neem (Azadirachta indica, leaves), Ivy Gourd (Coccinia grandis, leaves), Water Spinach (Ipomoea aquatica, leaves) and Skunkvine (Paederia foetida, leaves) which were collected from different local market of Dhaka, Bangladesh during November 2017 to February 2018. All the samples were processed in aseptic manner followed by homogenizing $10 \mathrm{~mL}$ of each sample with $90 \mathrm{~mL}$ normal saline and serially diluted up to $10^{-4}$ for microbiological assay (Ahmed et al., 2014; Sharmin et al., 2014; Jahan et al., 2018; Chakraborty et al., 2020).

\subsection{Isolation and enumeration of microorganisms}

From the dilutions $10^{-2}$ and $10^{-4}, 0.1 \mathrm{~mL}$ of each sample was introduced by means of spread plate technique onto the Nutrient agar (NA) and Sabouraud's dextrose agar (SDA) plates for the enumeration of total viable bacteria (TVB) and fungi, respectively. In order to isolate coliforms (especially, Escherichia coli and Klebsiella spp.), fecal coliform, Staphylococcus spp. and Pseudomonas spp., $0.1 \mathrm{~mL}$ of each sample from dilutions $10^{-2}$ and $10^{-3}$ was spread out onto MacConkey (MAC) agar, Membrane Fecal Coliform (mFC) agar, Manitol Salt Agar (MSA) and Pseudomonas agar (PA) plates, consecutively. NA, MAC, MSA and PA Plates were incubated for $24 \mathrm{hrs}$ at $37^{\circ} \mathrm{C}$. While SDA plates were incubated at $25^{\circ} \mathrm{C}$ for $48 \mathrm{hrs}$ and the incubation of $\mathrm{mFC}$ agar plates was carried out at $44.5^{\circ} \mathrm{C}$ for $24 \mathrm{hrs}$ (Jahan et al., 2018; Munshi et al., 2018; Chakraborty et al., 2020).

\subsection{Preparation of the samples for solvent extraction and conduction of antimicrobial assay}

For the preparation of methanolic and ethanolic extracts, the powdered form of each sample was prepared through grinding and $15 \mathrm{~g}$ of powder was added in $85 \mathrm{~mL}$ of ethanol and methanol in Durham's bottle. Then the bottles were kept in shaking water bath at $24^{\circ} \mathrm{C}$ for $24 \mathrm{hrs}$ at $130 \mathrm{rpm}$. Afterward, the pellets of the samples were collected following filtration of the extract solutions (Jahan et al., 2018; Chakraborty et al., 2020).
To observe the anti-bacterial properties of crude, hot water and solvent extracts of the green leafy vegetable samples against different previously isolated laboratory strains such as Escherichia coli, Pseudomonas spp., Vibrio spp., Klebsiella spp., Staphylococcus spp., Listeria spp., Salmonella spp. and Bacillus spp., agar well diffusion method was employed (Jahan et al., 2018; Chakraborty et al., 2020). At first, the lawn from each bacterial suspension $\left(10^{5} \mathrm{CFU} / \mathrm{mL}\right.$ or 0.5 OD measured by spectrophotometer) onto Mueller-Hinton agar (MHA) were prepared and $100 \mu \mathrm{l}$ (at a concentration of $\sim 11.1 \mathrm{mg} / \mathrm{mL}$ ) each of the crude, hot water, ethanolic and methanolic extracts were introduced into the wells formed on MHA (Jahan et al., 2018; Chakraborty et al., 2020). Buffer peptone water, absolute ethanol and methanol were used as negative controls while the antibiotic discs of gentamicin $(10 \mu \mathrm{g})$ were used as the positive control (Chakraborty et al., 2020). Plates were incubated at $37^{\circ} \mathrm{C}$ for $12-18 \mathrm{hrs}$ and examined for formation of the zone of inhibitions (mm).

\subsection{Assessment of the minimal inhibitory concentration (MIC) through broth micro-dilution method}

The antibacterial activity of natural products was studied by employing a microdilution method, using Mueller-Hinton (MH) broth culture media (Sharmin et al., 2014). A total of $100 \mu \mathrm{L}$ of the overnight ( 12 hrs) culture of each of the test bacteria was inoculated into the appropriately labelled sterile tubes containing $\mathrm{MH}$ broth (Oxoid Ltd, England) at the turbidity adjusted with $0.5 \mathrm{McF}$ arland standards. Green leafy vegetable samples at a concentration of $0.4,0.8,1.5,3,6,12$ and $24 \mathrm{mg} / \mathrm{mL}$ were introduced onward in the suspension. All the tubes were incubated at $37^{\circ} \mathrm{C}$ for $24 \mathrm{hrs}$. The least concentration $(\mathrm{mg} / \mathrm{mL})$ of each sample which visibly could retard the multiplication of the tested bacteria was considered as the MIC value (Sharmin et al., 2014).

\section{Results and discussion}

\subsection{Recovery of microorganisms from green leafy vegetable samples}

A vast array of pathogenic bacteria, fungi, viruses an d parasites may ruin vegetables (Beuchat, 2002). Raw vegetables can be bruised during processing and distribution, leading to the release of plant nutrients that can act as potential growth factors for microorganisms (Ahmed et al., 2014). To verify the fact, the microbiological analysis was carried out in the present study and microbial contaminations were evident. All the samples harbored total viable bacteria in an average of $10^{7} \mathrm{CFU} / \mathrm{g}$, while fungi were present in a range of $10^{4}$ - $10^{5} \mathrm{CFU} / \mathrm{g}$ (Table 1). All the samples conferred the presence of specific bacterial isolates to some extent. 
Table 1. Microbiological load in the tested samples.

\begin{tabular}{lcccccc}
\hline $\begin{array}{l}\text { Green Leafy vegetable } \\
\text { Samples (n) }\end{array}$ & $\begin{array}{c}\text { TVB } \\
(\mathrm{CFU} / \mathrm{g})\end{array}$ & $\begin{array}{c}\text { Fungi } \\
(\mathrm{CFU} / \mathrm{g})\end{array}$ & $\begin{array}{c}\text { Staphylococcus spp. } \\
\text { (CFU/g) }\end{array}$ & $\begin{array}{c}\text { Klebsiella spp. } \\
\text { (CFU/g) }\end{array}$ & $\begin{array}{c}\text { E. coli } \\
(\mathrm{CFU} / \mathrm{g})\end{array}$ & $\begin{array}{c}\text { Pseudomonas spp. } \\
(\mathrm{CFU} / \mathrm{g})\end{array}$ \\
\hline Neem (3) & $1.9 \times 10^{7}$ & $5.5 \times 10^{5}$ & $2.8 \times 10^{4}$ & $3.2 \times 10^{4}$ & 0 & $3.1 \times 10^{5}$ \\
Ivy Gourd (3) & $2.6 \times 10^{7}$ & $6.1 \times 10^{4}$ & $2.6 \times 10^{4}$ & $3.3 \times 10^{3}$ & 0 & $1.2 \times 10^{4}$ \\
Water Spinach (3) & $1.1 \times 10^{6}$ & $1.9 \times 10^{4}$ & $2.2 \times 10^{5}$ & $4.0 \times 10^{4}$ & 0 & $1.1 \times 10^{4}$ \\
Skunkvine (3) & $1.9 \times 10^{7}$ & $2.1 \times 10^{5}$ & $3.4 \times 10^{4}$ & $3.0 \times 10^{5}$ & $2.3 \times 10^{4}$ & $2.8 \times 10^{4}$ \\
\hline
\end{tabular}

$\mathrm{N}$ - Number of samples, TVB- Total viable bacteria. Average count (CFU/g) from all samples have been shown here. Fecal coliform was absent in all samples.

Staphylococcus spp., Klebsiella spp. and Pseudomonas spp. were encountered in all the samples in an average of $10^{4} \mathrm{CFU} / \mathrm{g}$. E. coli contamination was found only in Skunkvine leaves samples. Fecal coliform was totally absent in all the tested samples (Table 1). The presence of microbial contaminants in green leafy vegetables was in cohort with the previous studies on similar samples investigated in different parts of the world (Froder et al., 2007; Seow et al., 2012; Al-Holy et al., 2013; Ahmed et al., 2014).

\subsection{In vitro antibacterial activity of different extracts of green leafy vegetable samples}

The present investigation revealed that all the green leafy vegetable samples exhibited antibacterial activity (Tables 2-6). In almost all cases, the crude extract and the hot water extract of the samples showed no antibacterial activity (Tables 2-5). On the other hand, ethanolic and methanolic extracts of the samples were found to be effective in eliminating pathogens, possibly for the better solubility of the active components in organic solvents (Bhojane et al., 2014). Exceptionally for Skunkvine leaves samples, the crude extract showed antibacterial potential, while ethanolic and methanolic extracts remained to be ineffective (Table 5). All the samples had antibacterial effects against $E$. coli though results varied for other microorganisms (Tables 2-5). The growth of Listeria spp. was only restricted by the solvent extracts of Skunkvine leaves (Table 5). Among all the samples, the extracts of Ivy Gourd leaves failed to inhibit the majority of tested microorganisms (Table 3). Overall, ethanolic extracts were found to be more effective in eliminating pathogens than methanolic extracts in the present study. Although Sukanya et al. (2009) reported methanolic extracts to be more effective than ethanolic extracts of plant leaves. Dubey et al. (2010), Kim et al. (2013) and Bhat and Al-Daihan (2014) found effective and determinative anti-microbial activity in green leafy vegetables against the selected bacterial strains. In addition, the in vitro antibacterial activity of the samples in the present study was further supported by observing the results of MIC assay (Table 6). The highest concentration of the samples as MIC value was found at $12 \mathrm{mg} / \mathrm{mL}$ which was calculated in four cases. While the lowest concentration as MIC value was determined to be $3 \mathrm{mg} / \mathrm{mL}$. The average MIC value was $6 \mathrm{mg} / \mathrm{mL}$ against all tested isolates (Table 6). Sukanya et al. (2009) found the highest MIC value of $6 \mathrm{mg} / \mathrm{mL}$ and an average of 4 $\mathrm{mg} / \mathrm{mL}$ MIC in different extracts of plant leaves. Kim et al. (2013) reported MIC value of less than $10 \mathrm{mg} / \mathrm{mL}$ in the samples they tested.

\section{Conclusion}

Collectively, all the samples exhibited significant antibacterial activity as revealed from the findings of agar well diffusion method as well as of MIC assay. More research is needed to identify specific antibacterial compounds in the green leafy vegetables and their full spectrum of effectiveness. However, the present investigation verified the effectivity of the studied

Table 2. Antimicrobial activity of Neem leaves (Azadirachta indica)

\begin{tabular}{|c|c|c|c|c|c|c|c|c|}
\hline \multirow[b]{2}{*}{ Test bacteria } & \multicolumn{8}{|c|}{ Zone of Inhibition in diameter (mm) } \\
\hline & $\begin{array}{l}\text { Crude } \\
\text { fraction }\end{array}$ & $\begin{array}{c}\text { Negative } \\
\text { control } \\
(\mathrm{BPW}) \\
\end{array}$ & $\begin{array}{c}\text { Hot } \\
\text { water } \\
\text { extract }\end{array}$ & $\begin{array}{c}\text { Negative } \\
\text { control } \\
\text { (Ethanol) }\end{array}$ & $\begin{array}{l}\text { Ethanol } \\
\text { extract }\end{array}$ & $\begin{array}{c}\text { Negative } \\
\text { control } \\
\text { (Methanol) } \\
\end{array}$ & $\begin{array}{c}\text { Methanol } \\
\text { extract }\end{array}$ & $\begin{array}{c}\text { Positive control } \\
\text { (Gentamicin } \\
10 \mu \mathrm{g})\end{array}$ \\
\hline E. coli & 0 & 0 & 0 & 0 & $13 \mathrm{~mm}$ & 0 & $12 \mathrm{~mm}$ & $17 \mathrm{~mm}$ \\
\hline $\begin{array}{l}\text { Pseudomonas } \\
\text { spp. }\end{array}$ & 0 & 0 & 0 & 0 & $12 \mathrm{~mm}$ & 0 & $17 \mathrm{~mm}$ & $20 \mathrm{~mm}$ \\
\hline Vibrio spp. & 0 & 0 & 0 & 0 & $12 \mathrm{~mm}$ & 0 & $13 \mathrm{~mm}$ & $18 \mathrm{~mm}$ \\
\hline Bacillus spp. & 0 & 0 & 0 & 0 & $21 \mathrm{~mm}$ & 0 & 18 & $22 \mathrm{~mm}$ \\
\hline Klebsiella spp. & 0 & 0 & 0 & 0 & $13 \mathrm{~mm}$ & 0 & $19 \mathrm{~mm}$ & $22 \mathrm{~mm}$ \\
\hline $\begin{array}{l}\text { Staphylococcus } \\
\text { spp. }\end{array}$ & 0 & 0 & 0 & 0 & 0 & 0 & 0 & $20 \mathrm{~mm}$ \\
\hline Listeria spp. & 0 & 0 & 0 & 0 & 0 & 0 & 0 & $24 \mathrm{~mm}$ \\
\hline Salmonella spp. & $15 \mathrm{~mm}$ & 0 & 0 & 0 & $19 \mathrm{~mm}$ & 0 & $18 \mathrm{~mm}$ & $29 \mathrm{~mm}$ \\
\hline
\end{tabular}


Table 3. Antimicrobial activity of Ivy Gourd leaves (Coccinia grandis)

\begin{tabular}{|c|c|c|c|c|c|c|c|c|}
\hline \multirow[b]{2}{*}{ Test bacteria } & \multicolumn{8}{|c|}{ Zone of Inhibition in diameter (mm) } \\
\hline & $\begin{array}{l}\text { Crude } \\
\text { fraction }\end{array}$ & $\begin{array}{l}\text { Negative } \\
\text { control } \\
(\mathrm{BPW}) \\
\end{array}$ & $\begin{array}{c}\text { Hot } \\
\text { water } \\
\text { extract }\end{array}$ & $\begin{array}{c}\text { Negative } \\
\text { control } \\
\text { (Ethanol) }\end{array}$ & $\begin{array}{l}\text { Ethanol } \\
\text { extract }\end{array}$ & $\begin{array}{c}\text { Negative } \\
\text { control } \\
\text { (Methanol) }\end{array}$ & $\begin{array}{c}\text { Methanol } \\
\text { extract }\end{array}$ & $\begin{array}{c}\text { Positive control } \\
\text { (Gentamicin } \\
10 \mu \mathrm{g})\end{array}$ \\
\hline E. coli & 0 & 0 & 0 & 0 & $12 \mathrm{~mm}$ & 0 & $11 \mathrm{~mm}$ & $18 \mathrm{~mm}$ \\
\hline $\begin{array}{l}\text { Pseudomonas } \\
\text { spp. }\end{array}$ & 0 & 0 & 0 & 0 & 0 & 0 & 0 & $21 \mathrm{~mm}$ \\
\hline Vibrio spp. & 0 & 0 & 0 & 0 & 0 & 0 & 0 & $19 \mathrm{~mm}$ \\
\hline Bacillus spp. & 0 & 0 & 0 & 0 & $16 \mathrm{~mm}$ & 0 & $12 \mathrm{~mm}$ & $20 \mathrm{~mm}$ \\
\hline Klebsiella spp. & 0 & 0 & 0 & 0 & 0 & 0 & 0 & $20 \mathrm{~mm}$ \\
\hline $\begin{array}{l}\text { Staphylococcus } \\
\text { spp. }\end{array}$ & 0 & 0 & 0 & 0 & $15 \mathrm{~mm}$ & 0 & 0 & $20 \mathrm{~mm}$ \\
\hline Listeria spp. & 0 & 0 & 0 & 0 & 0 & 0 & 0 & $16 \mathrm{~mm}$ \\
\hline Salmonella spp. & 0 & 0 & 0 & 0 & 0 & 0 & 0 & $19 \mathrm{~mm}$ \\
\hline
\end{tabular}

Table 4. Antimicrobial activity of Water Spinach (Ipomoea aquatic)

\begin{tabular}{|c|c|c|c|c|c|c|c|c|}
\hline \multirow[b]{2}{*}{ Test bacteria } & \multicolumn{8}{|c|}{ Zone of Inhibition in diameter (mm) } \\
\hline & $\begin{array}{l}\text { Crude } \\
\text { fraction }\end{array}$ & $\begin{array}{l}\text { Negative } \\
\text { control } \\
(\mathrm{BPW})\end{array}$ & $\begin{array}{c}\text { Hot } \\
\text { water } \\
\text { extract }\end{array}$ & $\begin{array}{l}\text { Negative } \\
\text { control } \\
\text { (Ethanol) }\end{array}$ & $\begin{array}{l}\text { Ethanol } \\
\text { extract }\end{array}$ & $\begin{array}{l}\text { Negative } \\
\text { control } \\
\text { (Methanol) }\end{array}$ & $\begin{array}{c}\text { Methanol } \\
\text { extract }\end{array}$ & $\begin{array}{c}\text { Positive control } \\
\text { (Gentamicin } \\
10 \mu \mathrm{g})\end{array}$ \\
\hline E. coli & 0 & 0 & 0 & 0 & $20 \mathrm{~mm}$ & 0 & $20 \mathrm{~mm}$ & $20 \mathrm{~mm}$ \\
\hline $\begin{array}{l}\text { Pseudomonas } \\
\text { spp. }\end{array}$ & 0 & 0 & 0 & 0 & $16 \mathrm{~mm}$ & 0 & $13 \mathrm{~mm}$ & $24 \mathrm{~mm}$ \\
\hline Vibrio spp. & 0 & 0 & 0 & 0 & 0 & 0 & 0 & $20 \mathrm{~mm}$ \\
\hline Bacillus spp. & 0 & 0 & 0 & 0 & 0 & 0 & 0 & $21 \mathrm{~mm}$ \\
\hline Klebsiella spp. & 0 & 0 & 0 & 0 & $15 \mathrm{~mm}$ & 0 & 0 & $19 \mathrm{~mm}$ \\
\hline $\begin{array}{l}\text { Staphylococcus } \\
\text { spp. }\end{array}$ & 0 & 0 & 0 & 0 & $15 \mathrm{~mm}$ & 0 & $16 \mathrm{~mm}$ & $22 \mathrm{~mm}$ \\
\hline Listeria spp. & 0 & 0 & 0 & 0 & 0 & 0 & 0 & $25 \mathrm{~mm}$ \\
\hline Salmonella spp. & 0 & 0 & 0 & 0 & $15 \mathrm{~mm}$ & 0 & $12 \mathrm{~mm}$ & $20 \mathrm{~mm}$ \\
\hline \multicolumn{9}{|c|}{ Table 5. Antimicrobial activity of Skunkvine leaves (Paederia foetida) } \\
\hline \multirow[b]{2}{*}{ Test bacteria } & \multicolumn{8}{|c|}{ Zone of Inhibition in diameter $(\mathrm{mm})$} \\
\hline & $\begin{array}{l}\text { Crude } \\
\text { fraction }\end{array}$ & $\begin{array}{c}\text { Negative } \\
\text { control } \\
(\mathrm{BPW})\end{array}$ & $\begin{array}{c}\text { Hot } \\
\text { water } \\
\text { extract }\end{array}$ & $\begin{array}{c}\text { Negative } \\
\text { control } \\
\text { (Ethanol) }\end{array}$ & $\begin{array}{c}\text { Ethanol } \\
\text { extract }\end{array}$ & $\begin{array}{c}\text { Negative } \\
\text { control } \\
\text { (Methanol) } \\
\end{array}$ & $\begin{array}{c}\text { Methanol } \\
\text { extract }\end{array}$ & $\begin{array}{c}\text { Positive control } \\
\text { (Gentamicin } \\
10 \mu \mathrm{g})\end{array}$ \\
\hline E. coli & 0 & 0 & 0 & 0 & $15 \mathrm{~mm}$ & 0 & 0 & $17 \mathrm{~mm}$ \\
\hline $\begin{array}{l}\text { Pseudomonas } \\
\text { spp. }\end{array}$ & $12 \mathrm{~mm}$ & 0 & 0 & 0 & 0 & 0 & 0 & $28.44 \mathrm{~mm}$ \\
\hline Vibrio spp. & 0 & 0 & 0 & 0 & $19 \mathrm{~mm}$ & 0 & $15 \mathrm{~mm}$ & $20 \mathrm{~mm}$ \\
\hline Bacillus spp. & 0 & 0 & 0 & 0 & $16 \mathrm{~mm}$ & 0 & $14 \mathrm{~mm}$ & $22 \mathrm{~mm}$ \\
\hline Klebsiella spp. & 0 & 0 & 0 & 0 & $13 \mathrm{~mm}$ & 0 & $12 \mathrm{~mm}$ & $19 \mathrm{~mm}$ \\
\hline $\begin{array}{l}\text { Staphylococcus } \\
\text { spp. }\end{array}$ & 0 & 0 & 0 & 0 & 0 & 0 & 0 & $22 \mathrm{~mm}$ \\
\hline Listeria spp. & 0 & 0 & 0 & 0 & $17 \mathrm{~mm}$ & 0 & $18 \mathrm{~mm}$ & $24 \mathrm{~mm}$ \\
\hline Salmonella spp. & 0 & 0 & 0 & 0 & $13 \mathrm{~mm}$ & 0 & 0 & $28 \mathrm{~mm}$ \\
\hline
\end{tabular}

Table 6. Minimum Inhibitory Concentration (MIC) of the samples.

\begin{tabular}{|c|c|c|c|c|c|c|c|c|}
\hline \multirow{2}{*}{$\begin{array}{c}\text { Green Leafy } \\
\text { Vegetable Sample }\end{array}$} & \multicolumn{8}{|c|}{ Microorganisms } \\
\hline & $\begin{array}{l}\text { Klebsiella } \\
\text { spp. }\end{array}$ & E. coli & $\begin{array}{l}\text { Pseudomonas } \\
\text { spp. }\end{array}$ & $\begin{array}{l}\text { Bacillus } \\
\text { spp. }\end{array}$ & $\begin{array}{l}\text { Salmonella } \\
\text { spp. }\end{array}$ & $\begin{array}{l}\text { Listeria } \\
\text { spp. }\end{array}$ & $\begin{array}{c}\text { Staphylococcus } \\
\text { spp. }\end{array}$ & $\begin{array}{l}\text { Vibrio } \\
\text { spp. }\end{array}$ \\
\hline $\begin{array}{l}\text { Neem } \\
(\mathrm{mg} / \mathrm{mL})\end{array}$ & 6 & 6 & 3 & 3 & 3 & 3 & 6 & 6 \\
\hline $\begin{array}{l}\text { Ivy Gourd } \\
(\mathrm{mg} / \mathrm{mL})\end{array}$ & 6 & 3 & 3 & 3 & 6 & 6 & 12 & 6 \\
\hline $\begin{array}{l}\text { Water Spinach } \\
(\mathrm{mg} / \mathrm{mL})\end{array}$ & 6 & 6 & 12 & 12 & 3 & 6 & 6 & 6 \\
\hline $\begin{array}{l}\text { Skunkvine } \\
(\mathrm{mg} / \mathrm{mL})\end{array}$ & 3 & 3 & 6 & 12 & 6 & 3 & 3 & 6 \\
\hline
\end{tabular}


vegetables in their traditional uses against bacterial infections. The study findings also suggest that the tested green leafy vegetables could potentially be used in developing antimicrobials.

\section{Conflict of Interest}

Authors have no potential conflict of interest.

\section{Acknowledgement}

Authors would like to thank Stamford University Bangladesh for the financial and technical supports.

\section{References}

Ahmed, T., Urmi, N.J., Munna, M.S., Das, K.K., Acharjee, M., Rahman, M.M. and Noor, R. (2014). Assessment of microbiological proliferation and in vitro demonstration of the antimicrobial activity of the commonly available salad vegetables within Dhaka metropolis, Bangladesh. American Journal of Agriculture and Forestry, 2(3), 55-60. https:// doi.org/10.11648/j.ajaf.20140203.11

Al-Holy, M., Osaili, T., El-Sayed, S., AlShammari, E. and Ashankyty, I. (2013). Microbiological Quality of Leafy Green Vegetables Sold in the Local Market of Saudi Arabia. Italian Journal of Food Science, 25, 446-452.

Amagase, H. and Farnsworth, N.R. (2011). A review of botanical characteristics, phytochemistry, clinical relevance in efficacy and safety of Lycium barbarum fruit (Goji). Food Research International, 44(7), 1702-1717. j.foodres.2011.03.027

Beuchat, L.R. (2002). Ecological factors influencing survival and growth of human pathogens on raw fruits and vegetables. Microbes and Infection, 4(4), 413-423. https://doi.org/10.1016/S1286-4579(02) 01555-1

Bhat, R.S. and Al-Daihan, S. (2014). Phytochemical constituents and antibacterial activity of some green leafy vegetables. Asian Pacific Journal of Tropical Biomedicine, 4(3), 189-93. https://doi.org/10.1016/ S2221-1691(14)60230-6

Bhojane, P., DamLe, S., Thite, A. and Dabholkar V. (2014). Anti-microbial effects of some leafy vegetables - A comparative analysis. International Research Journal of Biological Sciences, 3(8), 2632.

Chakraborty, M., Afrin, T. and Munshi, S.K. (2020). Microbiological quality and antimicrobial potential of extracts of different spices. Food Research, 4(2), 375-379. https://doi.org/10.26656/fr.2017.4(2).303
Dhiman, K., Gupta, A., Sharma, D.K., Gill, N.S. and Goyal A. (2012). A review on the medicinal important plants of the family of Cucurbitaceae. Asian Journal of Clinical Nutrition, 4(1), 16-26. https://doi.org/10.3923/ajen.2012.16.26

Dubey, A., Mishra, N. and Singh, N. (2010). Antimicrobial activity of some selected vegetables. International Journal of Applied Biology and Pharmaceutical Technology, 1(3), 994-999.

Froder, H., Martins, C.G., De Souza, K.L.O., Landgraf, M., Franco, B.D. and Destro, M.T. (2007). Minimally processed vegetable salads: microbial quality evaluation. Journal of Food Protection, 70 (5), 1277-1280. https://doi.org/10.4315/0362-028X70.5.1277

Jahan, N., Noor, R. and Munshi, S.K. (2018). Microbiological analysis and determination of antimicrobial traits of green banana (Musa spp.) and papaya (Carica papaya). Stamford Journal of Microbiology, 8(1), 41-45. https://doi.org/10.3329/ sjm.v8i1.42439

Kesari, A.N., Gupta, R.K. and Watal G. (2005). Hypoglycemic effects of Murraya koengii on normal and alloxan-diabetic rabbits. Journal of Ethnopharmacology, 97(2), 247-251. https:// doi.org/10.1016/j.jep.2004.11.006

Khanna, A.K., Rizvi, F. and Chander, R. (2002). Lipid lowering activity of Phyllanthus niruri in hyperlipidemic rats. Journal of Ethnopharmacology, 82(1), 19-22. https://doi.org/10.1016/S0378-8741 (02)00136-8

Kim, S.J., Cho, A.R. and Han, J. (2013). Antioxidant and antimicrobial activities of leafy green vegetable extracts and their applications to meat product preservation. Food Control, 29(1), 112-120. https:// doi.org/10.1016/j.foodcont.2012.05.060

Matasyoh, J.C., Maiyo, Z.C., Ngure, R.M. and Chepkorir, R. (2009). Chemical composition and antimicrobial activity of the essential oil of Coriandrum sativum. Food Chemistry, 113(2), 526 529. https://doi.org/10.1016/j.foodchem.2008.07.097

Munshi, S.K., Haque, T. and Noor, R. (2018). Influence of multi-species biofilm formed in vitro from different environmental samples on the drugresistance traits of resident bacteria. Bangladesh Journal of Microbiology, 35(2), 108-114. https:// doi.org/10.3329/bjm.v35i2.42639

Rajeshkumar, N.V., Joy, K.L., Kuttan, G., Ramsewak, R.S., Nair, M.G. and Kuttan R. (2002). Antitumour and anticarcinogenic activity of Phyllanthus amarus extract. Journal of Ethnopharmacology, 81(1), 1722. https://doi.org/10.1016/S0378-8741(01)00419-6 
Rattanasena, P. (2012). Antioxidant and antibacterial activities of vegetables and fruits commonly consumed in Thailand. Pakistan Journal of Biological Sciences, 15(18), 877-882. https:// doi.org/10.3923/pjbs.2012.877.882

Seow, J., Agoston, R., Phua, L. and Yuk, H.G. (2012). Microbiological quality of fresh vegetables and fruits sold in Singapore. Food Control. 25(1), 39-44. https://doi.org/10.1016/j.foodcont.2011.10.017

Sharmin, M., Nur, I.T., Acharjee, M., Munshi, S.K. and Noor, R. (2014). Microbiological profiling and the demonstration of in vitro anti-bacterial traits of the major oral herbal medicines used in Dhaka Metropolis. SpringerPlus, 3, 739. https:// doi.org/10.1186/2193-1801-3-739

Sukanya, S.L., Sudisha, J., Hariprasad, P., Niranjana, S.R., Prakash, H.S. and Fathima, S.K. (2009). Antimicrobial activity of leaf extracts of Indian medicinal plants against clinical and phytopathogenic bacteria. African Journal of Biotechnology, 8(23), 6677-6682.

Yamamura, S., Ozawa, K., Ohtani, K., Kasai, R. and Yamasaki, K. (1998). Antihistaminic flavones and aliphatic glycosides from Mentha spicata. Phytochemistry, 48(1), 131-136. https:// doi.org/10.1016/S0031-9422(97)01112-6 